\title{
HISTORIA LITERATURY W OBJĘCIACH DARWINA?
}

Stwierdzenie, że żyjemy w wieku pluralizmu teorii, brzmi bardzo delikatnie. Eufemizm ten pozwala retorycznie złagodzić poczucie frustracji, jakie z jednej strony towarzyszy młodym adeptom badań literackich, próbującym opanować ich współczesny język i metodologię, z drugiej zaś - opanowuje (niekiedy przynajmniej) wytrawnych badaczy, którzy mniejszą czy większą część swej energii naukowej trawią na poszukiwaniach odpowiedniego i solidnego (a czasami, niestety, tylko efektownego) teoretycznego oparcia dla swoich literaturoznawczych rozpoznań. Jednym i drugim towarzyszy - do pewnego stopnia słuszne - przeświadczenie, że bez tego oparcia, którego dostarcza umocowanie własnego idiolektu badawczego w którymś z głównych, aktualnych nurtów refleksji teoretycznej, ani rusz. Wspomniane zaś poczucie frustracji, do którego niezbyt wypada się publicznie przyznawać, to jedno z literaturoznawczych tabu, nie licujące z panującym w naszej dyscyplinie - zapewne tak jak w każdej innej - comme il faut. Być może do opisu sytuacji, w jakiej znalazło się dziś literaturoznawstwo, dobrze pasuje metafora „czyściec Teorii”: znalazło się ono w miejscu, z którego nie wyjdzie, dopóki nie spłaci ostatniego grosza zaciągniętego $\mathrm{u}$ Teorii długu.

Można w związku z tym zadać pytanie: czy synteza polskiej literatury, jaka powstanie za lat dziesięć czy dwadzieścia, będzie wolna od ,-izmów”, czy też przeciwnie, będzie nimi przesiąknięta? O ile w ogóle powstanie, co nie jest wcale takie pewne, zważywszy na obecny wielogłos (hałas?) nieprzetłumaczalnych , języków" i niekompatybilnych ze sobą „,łłowników”, jakimi posługują się poszczególne teo- 
rie? (Zwróćmy uwagę na skromny wymiar implikowanego pytaniem projektu: chodzi o pojedynczą syntezę. Może będzie ich więcej?). Jeden tylko przykład trudności, jakich nastręcza takie przedsięwzięcie: jak - wobec toczącej się w ostatnich latach debaty na temat polskiego dyskursu „kresowego” czy też „kresoznawczego” i charakteru polskiej obecności na wschodnich rubieżach dawnej Rzeczpospolitej pisać o literaturze tego obszaru geograficzno-kulturowego? Jakimi kategoriami i jaką metodologią się posługiwać, by z jednej strony nie konstruować naukowej odnogi przedłużenia minionej polskiej supremacji (lub w wersji mocniejszej: dominacji) kulturowej, z drugiej zaś - nie zatrzeć „miękkiej” specyfiki polskiego dyskursu „kresoznawczego" na tle „twardych” dyskursów kolonialnych XIX- i XX-wiecznych europejskich potęg imperialnych? Władysław Panas snuł swego czasu projekt badań literackich na pograniczu etnicznym, które „,respektując różnice, zachowując i wydobywając odrębności”, pokażą w tekstach „rozmaite manifestacje inności, napięcia i kolizje, zmieszanie, podwójność i ambiwalencję, także te najbardziej dramatyczne, dotyczące kwestii tożsamości narodowej"'. Wizji tej, zbyt pospiesznie chyba zakwalifikowanej jako „kolonizatorska”, Bogusław Bakuła przeciwstawił swoją wizję komparatystyki integralnej². Czy można stanowiska te ze sobą uzgodnić, respektując stojące za każdym z nich, ważkie racje? Czy też pozostaje nam wybór jednej tylko spomiędzy tych dwu, w istocie niezupełnie ze sobą sprzecznych, możliwości? A może czeka nas poszukiwanie jeszcze innej perspektywy, jakiejś „trzeciej drogi”, której istnienia jeszcze się nie domyślamy? Przykład ten, zapewne jeden $\mathrm{z}$ wielu, jakie można by wskazać, uświadamia trudności stojące przed autorami przyszłej syntezy historycznoliterackiej. Czy nasza nauka o literaturze dysponuje dziś odpowiednim językiem dla tego rodzaju przedsięwzięcia? A może synteza ta pozostanie niewrażliwa na dylematy, w które kusicielsko wciaga literaturoznawstwo Teoria, i po-

\footnotetext{
1 Władysław Panas, O pograniczu etnicznym w badaniach literackich, w zbiorze: Wiedza o literaturze i edukacja. Księga referatów Zjazdu Polonistów, Warszawa 1995, pod red. Teresy Michałowskiej, Zbigniewa Golińskiego, Zbigniewa Jarosińskiego, Warszawa 1996, s. 613.

2 Bogusław Bakuła, Historia i komparatystyka. Szkice o literaturze i kulturze Europy Środkowo-Wschodniej XX wieku, Poznań 2000; por. tenże, Kolonialne i postkolonialne aspekty polskiego dyskursu kresoznawczego (zarys problematyki), ,Teksty Drugie” 2006, nr 6, s. 31-32.
} 
dąży inną, wolną od tych meandrów, drogą? Jakkolwiek nieprawdopodobne mogłoby się to nam w tej chwili wydawać.

Musimy zawiesić te pytania, trudno bowiem udzielić na nie obecnie sensownej odpowiedzi. Zgodzić się natomiast wypada, że błogostan panujący w przedpoststrukturalistycznej metodologii humanistyki jest niemożliwy do przywrócenia. Czy to jednak oznacza, że jesteśmy skazani na historię literatury, która rozpadnie się na wiele języków, by dopełnić dzieła spustoszenia rozteoretyzowanego Babel? Czy będzie to Historia literatury, czy też historia-literatury-z-takiego-a-takiego-punktu-widzenia? Kulturowa historia literatury? Jedno wiemy z całą pewnością: nie dekonstrukcjonistyczna, dekonstrukcjonizm bowiem jak wiadomo - nie przejawia w tym kierunku żadnego zapału, a przy tym u nas nieszczególnie się przyjął. Może w takim razie - ewolucjonistyczna?

Ewolucja badań literackich w XX w. (o ile zgodzimy się, że mamy tu do czynienia z modelem ewolucyjnym, a nie np. anarchicznym, bo rewolucyjność nie wchodzi raczej w grę) przebiegała w znacznej mierze pod znakiem inspiracji inter- i ekstra-, a w ostatnim czasie również trans-dyscyplinarnych. Na jej kierunkach i rezultatach zaważyła przede wszystkim, jak wiadomo, semiotyka (de Saussure'owska i Jakobsonowska) i strukturalizm z ich późniejszymi Derridiańskimi inwersjami i Foucaultowską teorią dyskursu, psychoanaliza (Freud, Jung, Lacan, w znacznie mniejszym stopniu Fromm), a także marksizm z jego socjologiczną perspektywą (ideologiczno-instytucjonalną proweniencję i specyficzną egzystencję marksistowskiego literaturoznawstwa w krajach Europy Środkowo-Wschodniej i ZSRR pomijam jako zjawisko aberracyjne i oby należące bezpowrotnie do annałów dziejów cywilizacji). Znacznie słabiej odcisnęła swoje piętno na rozwoju literaturoznawstwa fenomenologia, ku ubolewaniu polskich admiratorów i kontynuatorów myśli Ingardena. Tę listę wpływów, o rozmaitej intensywności i zasięgu, można by, rzecz jasna, znacznie wydłużyć, subtelnie cieniując poszczególne zjawiska.

W wyniku przekształceń, jakim poddany został w ciagu mniej więcej ostatniego ćwierćwiecza, przede wszystkim przy udziale radykalnego poststrukturalizmu, paradygmat humanistyki, rozpowszechnio- 
ny dziś jest w niej pogląd, że treść poznawcza naszego doświadczenia jest językowo „zapośredniczona” lub kulturowo „skonstruowana”, przez co nieobiektywna, ergo: niegodna zaufania, niespójna, obarczona błędem, a nawet całkowicie „wymyślona”. Kulturowo-językowym konstruktem okazuje się w tym świetle również, zaangażowany w poznanie rzeczywistości, podmiot. $Z$ irracjonalności tych przeświadczeń, ujawniającej się z całą moca, gdy wyciągnąc z nich ostateczne konsekwencje, nie zdawali i chyba nadal nie zdają sobie sprawy główni kreatorzy postmodernistycznego dyskursu, a także ich akolici, adepci i czeladnicy. Ponieważ ten punkt widzenia jest nie tylko modny, lecz także dominujący, i zarazem obowiązujący, w środowiskach akademickich wielu, jeśli nie statystycznej większości, uczelni na obu półkulach, poważniejsza dyskusja z nim toczy się z reguły w lokalizacjach niszowych dla dzisiejszej debaty humanistycznej. Podejmuje się ją na przykład na łamach pism konserwatywnych, takich jak znakomity amerykański kwartalnik „Modern Age”, a także w innych publikacjach o nastawieniu polemicznym wobec mainstreamu współczesnej humanistyki z jej upodobaniami i modami. Do najbardziej znanych antologii, wchodzących we frontalny spór z ponowoczesnością i jej licznymi, rozproszonymi residuami, należy przeszło 700-stronicowa Theory's Empire ${ }^{3}$. Natomiast $\mathrm{z}$ ostatnio opublikowanych u nas prac (w języku angielskim) warto wymienić, częściowo dotyczące tej problematyki (a ściślej jej literackiego i okołoliterackiego kontekstu), rozważania Doroty Heck w ksiazżce Four Dilemmas: Theory, Criticism, History, Faith. Sketches on the Threshold of Literary Anthropo$\log y^{4}$.

(Tu glossa. Obecność, a także perspektywy obecności naszej refleksji polonistycznej, czy ściślej: literaturoznawczej, w tym teoretycznej, w języku angielskim, to zagadnienie samo w sobie zasługujące

3 Theory's Empire. An Anthology of Dissent, ed. by Daphne Patai i Wilfrido H. Corral, New York 2005. Zob. polskie omówienie tej publikacji: Stefan Głowacki, Teoria literatury bez Teorii, ,Teksty Drugie” 2006, nr 3, s. 182-187.

4 Dorota Heck, Four Dilemmas: Theory, Criticism, History, Faith. Sketches on the threshold of literary anthropology, translated into English by Robert Kielawski, Kraków 2010. Zob. omówienie tej książki w: „The Sarmatian Review”, vol. 30, no. 3 (September 2010), s. 15291530 . 
na osobną uwagę. Tutaj mogę je jedynie zasygnalizować, kasandrycznym tonem przestrzegając, że alarmujące dane demograficzne, w połączeniu $\mathrm{z}$ rozwiązaniami stosowanymi nie tylko w instytucjach akademickich krajów członkowskich UE, takimi jak programy wymiany międzynarodowej, tzw. mobilność kadry naukowej, doktorantów i studentów, mogą w przyszłości doprowadzić do tego, że drugim obok polskiego językiem wykładowym polonistyki uniwersyteckiej będzie angielski. Nawet jeśliby ten czarny scenariusz się nie spełnił, przymus posługiwania się w badaniach literackich angielszczyzną wynika również z postępującej „globalizacji” nauki. Silnie odczuwanej potrzebie absorpcji istniejących języków i dyskursów w celu dostosowania się (doszlusowania?) do aktualnie obowiązujących w nauce tendencji i mód towarzyszy dewiza: ,chcesz, by cię czytano, cytowano, posługuj się dyskursem zrozumiałym dla większości i publikuj, najlepiej po angielsku" - zasada oparta na stricte pragmatycznym kryterium pomiaru tzw. impact factor, czyli wskaźnika wpływu badacza i jego prac na daną dziedzinę wiedzy, mierzonego przez internetowy licznik cytowań. Wypada wyrazić nadzieję, że polscy literaturoznawcy - o ile zdecydują się wcielić w życie powyższą dewizę - nie tylko nie będą zbyt łatwo ulegali pokusie odtwórczej repetycji komunałów globalnego dyskursu humanistycznego, lecz także sami, za pośrednictwem swoich prac, będą podejmowali próby oddziaływania, choćby w skromnej mierze, na kształt współczesnego dyskursu literaturoznawczego w świecie - tak w zakresie ustaleń historycznoliterackich, o co względnie łatwiej, jak i propozycji teoretycznych, co stanowi nie lada wyzwanie).

Wśród pomysłów na uratowanie badań literackich od ,zupowatości”, w waką popadły pod wpływem postmodernistycznych ,innowacji”, pojawiają się i takie - znamienne dla czasów, w których żyjemy - by zintegrować naukę o literaturze z naukami przyrodniczymi ${ }^{6}$. Idea

\footnotetext{
5 Nawiązuję do metafory użytej przez Włodzimierza Boleckiego w wystapieniu Pytania o przedmiot literaturoznawstwa, w: Polonistyka w przebudowie. Literaturoznawstwo - wiedza o języku - wiedza o kulturze - edukacja. Zjazd Polonistów. Kraków, 22-25 września 2004, zespół red.: Małgorzata Czermińska (przewodn.) [et al.], t. 1, Kraków 2005, s. 12.

${ }^{6}$ Integrację tę zwiastują m.in.: Edward Slingerland, What Science Offers the Humanities. Integrating Body and Culture (Cambridge 2008) i Jonathan Gottschall, Literature, Science, and
} 
ta wydaje się o tyle paradoksalna, że te dwa obszary postrzegano zazwyczaj jako skonfliktowane ze soba, a tradycyjna struktura akademii, oparta na głębokiej specjalizacji, dodatkowo utrudniała przez długi czas „humanizację” dziedzin ścisłych, tych ostatnich zaś nie zachęcała do transmitowania idei na teren humanistyki. Ponadto, to właśnie naukom ścisłym, obrośniętym kultem technologii i obudowanym mitem wymiernych, pragmatycznych zastosowań nieosiagalnych dla dyscyplin humanistycznych, przypisuje się wytworzenie społeczeństwa technokratycznego - i tym samym pośrednia, bądź nawet bezpośrednią, odpowiedzialność za upadek zachodniej kultury ${ }^{7}$. Czy biorąc to wszystko pod uwagę, mogą one mieć do odegrania jakąś rolę w odnowieniu humanistyki?

Jedną z przesłanek zbliżenia z sciences jest, silnie odczuwana przez część środowisk uniwersyteckich, potrzeba przemodelowania współczesnego dyskursu humanistycznego. Miałoby ono doprowadzić do zneutralizowania skutków radykalnego sceptycyzmu epistemologicznego, któremu przypisuje się na ogół odpowiedzialność za, panoszący się w naukach humanistycznych, relatywizm i anarchię metodologiczna. U podstaw krytyki tych zjawisk stoi zasadniczy sprzeciw wobec poglądu, jakoby prawom dyskursu przysługiwała nadrzędna rola w stosunku do praw nauki, czy też, inaczej rzecz ujmując, jakoby wszystko było retoryka, a nauka stanowiła domenę słów, niezdolnych do uchwycenia rzeczywistości. Stąd, zauważalny w niektórych, przede wszystkim amerykańskich, kręgach uniwersyteckich, zwrot ku zdroworozsąakkowemu podejściu nauk ścisłych, a także społecznych, odróżniających się od humanistyki akademickiej tym, że są jak najdalsze od postrzegania dyskursu naukowego jako konstruktu narzucanego rzeczywistości w wyniku takich czy innych interesów, stosunków władzy czy praktyk kulturowych. (Nie zapominajmy przy tym, że zdrowy rozsądek, stojący za tym przeświadczeniem, to jedna z naj-

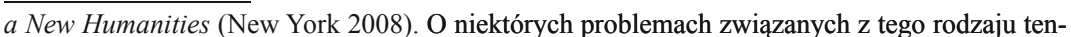
dencją do „przezwyciężania dualizmu” nauki pisałem w artykule Dokad zmierza humanistyka? O sytuacji wewnatrz $i$ wokót dyskursu humanistycznego (i teoretycznoliterackiego) na Zachodzie, postkolonializmie i... etyce, ,Teksty Drugie” 2004, nr 6, s. 199-211.

7 Por. Wolfgang Smith, Science and the Restoration of Culture, „Modern Age”, vol. 43, no.1 (Winter 2001), s. 91. 
bardziej podejrzanych dla postmodernistycznego światopoglądu kategorii i zarazem jeden z najczęstszych obiektów ataków „mistrzów podejrzeń"). Niechętni owocom, jakie postmodernizm wydał w dziedzinach humanistycznych, scjentystycznie usposobieni krytycy jego wpływu na naukę o literaturze chcieliby widzieć w uprawianej przez siebie dyscyplinie przede wszystkim zapis poznania korespondującego z rzeczywistością. Rzeczywistość bowiem - twierdzą na przekór dominującemu dyskursowi postmodernistycznemu - jest dostępna umysłowi i komunikowalna za pomocą narzędzi, pozostających do dyspozycji ludzkości na danym etapie cywilizacyjnym. W rozumowaniu tym kryje się sporo racji, a możemy przypuszczać, że np. fizycy, bez względu na kraj, język i pochodzenie etniczne, wybuchnęliby zgodnym śmiechem na tezę o narracyjnym charakterze teorii względności czy konstruktywistycznych założeniach zasady nieoznaczoności Heisenberga...

Humanistyka, w tym również jej uniwersytecka awangarda, opiera się na fundamentalnej wierze w kulturę i siłę płynącą $\mathrm{z}$ jej autonomii (,,omnis cultura ex cultura”) - w przekazywaną z pokolenia na pokolenie zdolność samoregulacji, tę swoistą potencję „soteriologiczną", przejawiającą się zdolnością do podźwignięcia człowieka i ludzkości (narodów, społeczeństw), do dokonania zmiany. Derrida, pomimo wpisanej w jego myśl polemiki z całą niemal tradycją epistemologiczną, w pewnym sensie jeszcze mocniej tę autonomię utwierdził, głosząc, że pismo (tekst) jest „wszystkim” - , il n'y a pas de hors-texte”. Literatura stać się mogła przez to autonomiczną sferą rzeczywistości, a właściwie tekstowym wszechświatem, który - niczym matrix - przeciwstawia się światu zewnętrznemu, zamiast zajmować wobec niego pozycję referencjalną. Skwapliwie podchwyciwszy ten pogląd, niektórzy literaturoznawcy - zafascynowani niekoniecznie i nie tyle samym Derrida, co raczej perspektywami, jakie otwiera dekonstruowanie tekstów - cieszą się w swej opinii przywilejem dostępu do ostatecznej, „najwyższej” rzeczywistości. Tę zaś postrzegają jako hermetycznie zamkniętą $w$ sferze literatury - i tym samym odartą $z$ metafizyki, wytrąconą z perspektywy eschatologii, pozbawioną związku z transcendencją, stanowiącą swego rodzaju sublimację ,tego, co reli- 
gijne". Bodaj najbardziej spektakularnym przykładem tego spojrzenia na literaturę jest tzw. chrześcijańska dekonstrukcja8 ${ }^{8}$.

Argumenty przeciwko szeroko pojętemu myśleniu konstruktywistycznemu - którego przedłużenie stanowi pantekstualizm, głoszący zerwanie łączności między językiem a rzeczywistością w wyniku przekonania, że jesteśmy ,uwięzieni w języku” - napływają z różnych stron. Nie tylko ze środowisk konserwatywnych, jeśli orientować mapę omawianych zjawisk według róży wiatrów ideologicznych. Niektórzy amerykańscy uczeni przypominają, że ,podstawą narracyjności [tj. umożliwiającego elementarne rozumienie świata sekwencyjnego sposobu porządkowania postrzeganych (relacjonowanych) zjawisk z uwzględnieniem ,aktora”, „,fabuły”, „scenerii”, ,rekwizytów" etc. - D.S.] jest myślenie przyczynowe, jedna ze zdroworozsądkowych kategorii, rozpoznana przed stuleciem przez Williama Jamesa"" (dodajmy, nie przez niego pierwszego, jej rodowód sięga przecież korzeniami Arystotelesowskiego racjonalizmu). Jeśli zaś szukać oparcia w koncepcjach bliższych współczesności, uznanie (m.in. przez językoznawstwo kognitywne) narracyjności i matrycy przyczynowej za zasadniczą ramę, w obrębie której rozwijają się ludzka myśl i komunikacja, jest ,zbieżne z dostrzeżeniem przez socjobiologa Wilsona w myśleniu przyczynowym zasady epigenetycznej”, tj. ewoluującej zdolności rozumienia świata, dziedziczonej drogą pozagenetyczną. Blisko już stąd do poglądu, że w porządek rzeczy istniejący w przyrodzie wpisana jest pewna konieczność, którą można odkryć ludzkim umysłem, a która wydaje się obiektywną własnością natury. Jeśli zatem przyjać, że „narracja służy przede wszystkim nadaniu spójnego kształtu zdarzeniom życia społecznego”, wówczas „przypisanie przyrodzie konieczności wskazuje na głęboką predyspozycję do od-

8 Zob. np. Gerald Cornelius Monsman, Walter Pater's Art of Autobiography, New Haven 1980; Clyde de L. Ryals, The Concept of Becoming in “Marius the Epicurean”, „Nineteenth Century Literature" 1988, no. 43, s. 157-174; W.D. Shaw, Victorians and Mystery. Crisis of Representation, New York 1990. Podaję za: Joseph Carroll, Evolution and Literary Theory, Columbia 1995, s. 129.

9 Nancy Easterlin, Bioepistemology and the Foundation of Literary Theory, w: Theory's Empire. An Anthology of Dissent, dz. cyt., s. 629. Jeśli nie zaznaczono inaczej wszystkie cytaty $\mathrm{z}$ jęz. angielskiego w tłum. autora. 
krywania porządku przyczynowego tkwiącego w naturze"10. Obie te własności ludzkiego myślenia stanowią, zdaniem bioepistemologów, „techniki adaptacyjne" umożliwiające zrozumienie (a zatem i opanowanie) relacji między zdarzeniami (przedmiotami). Jeżeli przy tym okaże się, że odkryty w danym momencie porządek rzeczy nie jest ich „faktyczną" własnością, a nadaną mu przez umysł konstrukcją, nie implikuje to błędu subiektywizmu i konieczności powrotu do radykalnego sceptycyzmu. Potwierdza jedynie proces rozwijania się naszych władz poznawczych, które dzięki tego rodzaju doświadczeniom nieustannie ewoluuja, przechodząc od jednego poziomu „względnej [tj. tymczasowej - D.S.] adekwatności" ${ }^{11}$ do drugiego, stosownie do kontekstu i uwarunkowań aktu poznawczego. W ten sposób objaśnia się m.in. kwestię rzekomej niekompatybilności ludzkiego języka i zewnętrznej rzeczywistości, podnoszoną przez współczesnych nominalistów jako rzekomy dowód przeciwko zwolennikom realizmu.

Jakie perspektywy otwiera przed nauką o literaturze i krytyką literacką stanowisko, które zdołałem tu naszkicować jedynie w ogólnych konturach, a które określa się mianem darwinizmu czy też ewolucjonizmu w badaniach literackich? Niektórzy uważają że „teorie psychologiczne zbieżne z biologiczną teorią ewolucyjną mogą pomóc nam rozwiązać sprzeczności pomiędzy teorią a praktyka, jakie nękają dziś badania literackie" ${ }^{12}$. Głównym promotorem tak ukierunkowanej przebudowy literaturoznawstwa, zwanym założycielem ,literackiego darwinizmu", jest amerykański badacz Joseph Carroll, głoszący potrzebe ,adaptacyjnych” czy też „ewolucjonistycznych” badań literac$\mathrm{kich}^{13}$. Projekt, rozwijany od kilkunastu lat przez niego i zgromadzonych wokół niego uczonych ${ }^{14}$, opiera się na założeniu, że humanistyka

\footnotetext{
10 Tamże.

11 Tamże, s. 630.

12 Tamże, s. 621.

13 Pierwszą w języku polskim (i jak dotąd jedyną znaną mi) wzmiankę o tej teorii przedstawiła nieoceniona Ewa Domańska w szkicu Jakiej metodologii potrzebuje współczesna humanistyka?, ,Teksty Drugie” 2010, nr 1-2, s. 45-55.

14 Współpracują z Carrollem m.in.: Jonathan Gottschall, John Johnson i Dan Kruger. Krąg badaczy stosujących metodę adaptacyjną do analizy tekstu literackiego rozszerza się w ostatnich latach o nowe nazwiska. Należą do niego m.in.: rusycysta z Uniwersytetu Texas A\&M w College Station Brett Cooke, a także Brian Boyd, Ian Jobling, Michelle Scalise Sugiyama,
} 
w ogóle, a nauka o literaturze w szczególności, winna - pod wpływem tzw. neodarwinizmu - uwzględniać w swej metodologii fakt istnienia ewoluującej natury tego "literackiego zwierzęcia" ${ }^{15}$, jakim jest człowiek. Stałe („genetyczne”) wyznaczniki tej natury, zakreślające ogólne ramy i nadające kształt formacji kulturowej danej epoki (okresu, stylu) itd., podlegają w wyniku oddziaływań zewnętrznych modyfikacjom, dostosowując się do aktualnych uwarunkowań środowiska, czyli odpowiednio się do niego adaptując. Istnienie tej ewoluującej „natury kulturowej” mają potwierdzać odkrycia socjobiologii (m.in. Edwarda O. Wilsona) i psychologii ewolucyjnej (m.in. Michaela Tomasello ${ }^{16}$ ), dokonywane mniej więcej od połowy lat 70 . XX w. Zafascynowany nowatorskim ujęciem propagowanym przez te dyscypliny, Carroll ogłasza w 2006 r. nie bez satysfakcji, że „w ciągu ostatnich piętnastu mniej więcej lat badacze literatury zaczęli asymilować odkrycia ewolucyjnych nauk społecznych, i obecnie badacze ci stanowią odrębny nurt w teorii literatury i krytyce literackiej" ${ }^{17}$. Autor projektu „literackiego darwinizmu” sam przyznaje, że to właśnie on od początku lat 90., sfrustrowany ,irracjonalizmem i tekstualizmem dominujących doktryn literackich" ${ }^{18}$, zainteresował się ewolucjonistycz-

Barbara Riebling, Robert Storey, David Barash, Nanelle Barash i wymieniana w tym artykule Nancy Easterlin. Bibliografię niektórych ważniejszych prac z zakresu ewolucjonizmu literackiego podaje artykuł: Brian Boyd, Literature and Science. Doomed Reductionism or Evolutionary Literary Pluralism?, „Evolutionary Psychology” 2008, vol. 6, no. 1, s. 82-84, za: http:// www.epjournal.net/filestore/ep068084.pdf [dostęp 13.01.2011].

15 Określenie pochodzi z tytułu książki The Literary Animal. Evolution and the Nature of Narrative, ed. by Jonathan Gottschall, David Sloan Wilson, Evanston 2005.

${ }_{16}$ Zob. np. Michael Tomasello, The Human Adaptation for Culture, ,Annual Review of Anthropology" 1999, no. 28, s. 509-529. Tomasello stawia tam tezę, że w pewnym momencie w dziejach świata doszło do tajemniczego, niepospolitego ,wydarzenia genetycznego”, w wyniku którego ludzie nabyli, odróżniające ich od pozostałych ssaków naczelnych, zdolności do akumulowania modyfikacji poznawczych (kulturowych) w czasie, a więc - mówiąc innym językiem - do tworzenia kultury i uczenia się za jej pośrednictwem. Jednak to nie owo nieznane ,wydarzenie genetyczne" samo w sobie jest odpowiedzialne za różnorodne formy i przejawy kultury. Jak twierdzi Tomasello, zdarzenie to zaledwie ,otworzyło drogę nowym procesom społecznym i kulturowym”, które - już bez dalszego udziału tego rodzaju ,zmian genetycznych” - zaowocowały swoistymi własnościami ludzkiego poznania, takimi jak zdolność ewoluowania (por. tamże, s. 526).

17 Joseph Carroll, Adaptationist Literary Study. An Introductory Guide, „Ometeca”, no. 10 (2006), s. 18.

18 Tenże, Literary Darwinism. Evolution, Human Nature, and Literature, New York 2004, s. XVI. W osobistej wypowiedzi (zob. przyp. 21) Carroll dopowiada, że na kierunku jego na- 
nymi perspektywami socjobiologii i psychologii ewolucyjnej. Impuls ten zaowocował trwałą fascynacją i doprowadził Carrolla do zainicjowania własnego projektu badań inkorporujących kategorie i pojęcia zaczerpnięte z obu wymienionych dyscyplin. Pierwszy, obszerny wykład nowej teorii przedłożony został przez badacza w monumentalnej pracy Evolution and Literary Theory (1995), która stanowiła swego rodzaju manifest i ,wyznanie wiary” jej autora, a także definiowała nowy obszar badań i precyzowała ich problematykę.

Carroll odwołuje się w swoim projekcie do kumulatywnej teorii transmisji kulturowej, wyłożonej m.in. w książce Tomasella Kulturowe źródta ludzkiego poznawania ${ }^{19}$. Jednym $\mathrm{z}$ centralnych założeń tej teorii jest przeświadczenie, że ludzie, podobnie jak różne gatunki zwierząt, charakteryzują się posiadaniem, typowego dla swego gatun$\mathrm{ku}$, kompletu zachowań (resp. dyspozycji), uwarunkowanych czy też zapośredniczonych genetycznie, a przekazywanych - w tempie znacznie szybszym niż w przypadku cech biologicznych - z pokolenia na pokolenie. W kształtowaniu ludzkiego poznania i ufundowanej na nim kultury Tomasello uznaje rolę dwu czynników: biologii i środowiska:

Współczesne poznanie dorosłego człowieka to rezultat nie tylko procesów ewolucji biologicznej, lecz także innych procesów, które ewolucja ta umożliwiła zarówno w czasie kulturowo-historycznym, jak i ontogenetycznym ${ }^{20}$.

Przeniesiona w obszar refleksji nad wytworami ludzkiej kultury, teoria ta interpretuje je w swoiście pojętych, progresywistycznych kategoriach Darwinowskich. Jak przyznaje Carroll, nie chodzi tu o ufundowanie kolejnej szkoły badawczej czy stworzenie ,ruchu”, lecz o zasadnicze przebudowanie ogólnej ramy, w jakiej uprawia się badania literackie, poprzez dostrzeżenie, że wszelkie ludzkie zachowanie, w tym również wytwory indywidualnej i zbiorowej wyobraźni, nabie-

\footnotetext{
ukowych poszukiwań zaważyło również doświadczenie odrzucenia wiary i zajęcie skrajnego stanowiska ateistycznego.

19 Michael Tomasello, Kulturowe źródła ludzkiego poznawania, przeł. Joanna Rączaszek, Warszawa 2002.

20 Tenże, The Human Adaptation for Culture, dz. cyt., s. 526.
} 
rają nowego, ważkiego wymiaru, gdy obserwuje się je z perspektywy ewolucjonistycznej ${ }^{21}$. Deklaracja ta nie rozwiewa jednak fundamentalnej wątpliwości: czy nie mamy tutaj do czynienia z projektem skrajnej deautonomizacji badań literackich?

Zanim spróbujemy na to pytanie odpowiedzieć, zastanówmy się, co interesującego z badawczego punktu widzenia ma ,literacki darwinizm" do zaoferowania w odniesieniu do jednostkowego utworu literackiego.

Na przykład o powieściach Joseph Carroll powiada, że:

Odzwierciedlają one punkt widzenia, swoisty sposób organizowania świata, tak iż upodabnia się on do określonych potrzeb artysty, właściwego mu sposobu organizowania swoich spostrzeżeń, myśli i odczuć. Gdy czytamy powieści, uczestniczymy zastępczo w punkcie widzenia pisarza - w całej jego wizji świata. Dowiadujemy się w ten sposób, nie tylko o tym, co zostaje przedstawione, lecz także o tym, jak pisarz patrzy na różne rzeczy. To wiedza, która przydaje się jako rodzaj informacji społecznej, lecz możemy ją też wykorzystać bardziej praktycznie, ucząc się dzięki niej możliwych strategii radzenia sobie z wyzwaniami, jakie stają przed nami w naszym własnym życiu²2.

Realizując tak zdefiniowane cele analizy literackiej, badacze spod znaku teorii adaptacyjnej przyglądają się m.in. kanonicznym tekstom literatury angielskiej, a także powszechnej - np. takim powieściom, jak Wichrowe Wzgórza, Portret Doriana Graya, Duma i uprzedzenie, Lolita Nabokova czy My Zamiatina, a także poezji Wordswortha, a nawet - Iliadzie ${ }^{23}$. Wykorzystują wobec nich, biorąc pod uwagę kon-

${ }^{21}$ Zob. Joseph Carroll, What is Literary Darwinism? An Interview with David DiSalvo, „Neuronarrative”, February 27, 2009, za: http://neuronarrative.wordpress.com/2009/02/27/ what-is-literary-darwinism-an-interview-with-joseph-carroll [dostęp 4.01.2011].

22 Tamże.

23 Zob. np. Joseph Carroll, The Cuckoo's History. Human Nature in Wuthering Heights, „Philosophy and Literature”, vol. 32, no. 2 (October 2008); tenże, Aestheticism, Homoeroticism, and Christian Guilt in The Picture of Dorian Gray, „Philosophy and Literature” vol. 29, no. 2 (October 2005); tenże, Human Nature and Literary Meaning. A Theoretical Model Illustrated with a Critique of "Pride and Prejudice", w: The Literary Animal. Evolution and the Nature of Narrative, dz. cyt.; Brian Boyd, The Art of Literature and the Science of Literature, ,American Scholar", vol. 77, no. 2 (Spring 2008); Brett Cooke, Human Nature in Utopia: Zamyatin 's "We", Evanston 2002; Nanelle Easterlin, Psychoanalysis and "The Discipline of Love", 
tekst historyczny, kulturowy itp., behawioralno-kognitywistyczne instrumentarium analityczne, umożliwiające rozpoznanie w postaciach występujących w utworach, charakterystycznych dla ludzkości, replikowalnych wzorców zachowań i modeli poznania. Tego rodzaju postępowanie z twórczością artystyczną wynika z przeświadczenia, że oparcie dla badań literackich stanowią dziś - oczywiście, poza biologią ewolucyjną - również adaptacjonistycznie ukierunkowane nauki społeczne. Mają one dostarczyć literaturoznawcy-darwiniście

najbardziej gruntownego, szczegółowego przewodnika do rzeczywistej treści i struktury ludzkiej natury, którym będą się mogły posłużyć do analizy treści i form literackich przedstawień, perspektywy autora i reakcji czytelników ${ }^{24}$.

Takie sformułowanie relacji między dyscyplinami wynika z zaakceptowania pewnych, zasadniczych dla omawianego tu projektu, założeń definiujących wspólną dla literaturoznawstwa i bioepistemologii przestrzeń:

Badacze literatury - adaptacjoniści przyjmują podstawową logikę adaptacyjnego rozumienia ludzkiego zachowania. W zgodzie zarówno z psychologami ewolucyjnymi, jak i większością pisarzy i teoretyków literatury od czasów Arystotelesa po drugą połowę XX w., wierzą w „ludzką naturę”. To znaczy wierza, że ludzie we wszystkich wiekach i kulturach wykazują wspólny, podstawowy zestaw motywów, uczuć i sposobów myślenia. Wierzą też, że literatura powszechnie opisuje ludzką naturę, że jest tej natury wytworem i że zaspokaja jej potrzeby ${ }^{25}$.

Darwinizm literacki przypomina zatem wcale nienowa, lecz zapoznaną (bo jakże niemodną dziś) prawdę, że twórczość literacka stanowi medium otwierające dostęp do tego wszystkiego, co konstytuuje świat człowieka: do jego trosk, obsesji i dążeń, jego motywów, emocji

\footnotetext{
„Philosophy and Literature”, vol. 24, no. 2 (October 2000); Jonathan Gottschall, Homer's Human Animal. Ritual Combat in the "Iliad”, „Philosophy and Literature”, vol. 25, no. 2 (October 2001).

${ }^{24}$ Joseph Carroll, Adaptationist Literary Study. An Introductory Guide, dz. cyt., s. 19.

25 Tamże.
} 
i charakteru. Chodzi - po prostu - o najpotoczniej pojmowaną funkcję poznawczą literatury, pozwalająca czytelnikom obcującym z utworem czerpać zeń wiedzę o świecie i o własnej w nim egzystencji, uczyć się pewnych umiejętności i doskonalić w innych, wreszcie planować własne strategie i cele życiowe.

Optymistycznie - wręcz sielankowo - brzmi niedawno wyrażone przez Carrolla przypuszczenie:

Kto wie? Może za dziesięć lub dwadzieścia lat, patrząc wstecz, historycy kultury będą zaprzeczali temu, że nauki humanistyczne i ewolucjonistyczne nauki społeczne kiedykolwiek znajdowały się we wzajemnym konflikcie. Integracja nauki o historii z poznaniem ludzkich uniwersaliów stanie się standardowym wyposażeniem w badaniach literackich. Humanistyczna umiejętność zręcznego operowania reprezentacjami kulturowymi wpłynie gładkim i harmonijnym strumieniem w Darwinowskie odkrycia na temat podstawowych cech ludzkiej natury. Humanistyczna wrażliwość na subtelne odcienie tonu i stylu dzieł literackich połączy się zwinnie z rygorystyczną analizą empiryczną mechanizmów poznawczych, a łatwość pisania elegancką, zniuansowaną prozą zespoli szczęśliwie z surową logiką metodologii kwantytatywnej. Uczeni i naukowcy parający się badaniami literackimi będą wdzięcznie balansować pomiędzy bezosobistą, obiektywną analizą nauki a zaangażowaniem humanistyki ${ }^{26}$.

Ujmująca wizja synergii, nakreślona przez projektodawcę „literackiego darwinizmu", nie przesłania jednak faktu, że nurt ten, choć spektakularnie wiąże dziedziny tak krańcowo od siebie odległe pod względem przedmiotowym i posługujące się odmiennymi metodologiami, jak biologia, psychologia i nauka o literaturze, jest kolejną spekulatywną teorią literatury. Pod tym względem niezbyt odbiega od teorii poststrukturalistycznych, niezależnie od deklaracji, że się od nich odżegnuje. Podobnie jak psychologia ewolucyjna, może dostarczyć atrakcyjnych i inspirujących wglądów w literaturę jako sferę ludzkiej aktywności kognitywno-kulturotwórczej. I podobnie jak psy-

${ }_{26}$ Joseph Carroll, An Evolutionary Paradigm for Literary Study, ,Style”, vol. 42, nos. 2-3 (Summer/Fall 2008), s. 135. 
chologia ewolucyjna, za sprawą spekulatywności swoich twierdzeń, nie jest falsyfikowalny.

$\mathrm{Z}$ drugiej strony, w odniesieniu do ludzkiego poznania i jego społeczno-kulturowych uwarunkowań, teoria ta umożliwia wyjaśnienie wielu zjawisk, które w innych ujęciach pozbawione są satysfakcjonującego uzasadnienia. W jej optyce np. postmodernistyczne zwątpienie w zdolności poznawcze człowieka i możliwości referencyjne języka jako instrumentu zapisu epistemologicznej empirii, a także współczesna fetyszyzacja teorii byłyby - jak można domniemywać - kolejnym, zapewne nieuniknionym, lecz szczęśliwie nie ostatnim, etapem ewolucji ludzkiego poznania. Etap ten - mamy prawo przypuszczać, biorąc pod uwagę przesłanki teorii ewolucjonistycznej - być może był potrzebny do zdystansowania się od nadmiaru pewności siebie i optymizmu badawczego, jakie cechowały strukturalizm, lecz zarazem przyniósł anarchię oraz rozliczne aporie, które wymagają przezwyciężenia, jeżeli dalsze, sensowne, zdyscyplinowane uprawianie humanistyki, w tym nauki o literaturze, ma w ogóle być możliwe i prowadzić do prawomocnych rezultatów, wykraczających poza serie subiektywnych, raczej krytycznoliterackich niż literaturoznawczych, „błędnych odczytań” czy też, jak kto woli, „nieodczytan””.

Jakkolwiek będziemy oceniali przyszłe skutki ewolucjonizmu dla prowadzonych pod jego auspicjami badań literackich (które u nas nie znajdują się jeszcze nawet $w$ fazie zarodkowej), jedno wydaje się nie podlegać wątpliwości: mamy do czynienia $\mathrm{z}$ odrębna, wyraziście zarysowaną propozycją przezwyciężenia impasu, w jakim znalazła się humanistyka po poststrukturalizmie. Nie jest to jednak, należy zauważyć, propozycja neutralna pod względem ideologicznym. Przezwyciężenie to przebiega bowiem w duchu materializmu, co wynika wprost z przyjętych przez literacki ewolucjonizm założeń filozoficznych. Nurt ten, wsparty teorią konsyliencji Wilsona ${ }^{27}$, rozpościera przed nauka, a za jej pośrednictwem przed całą ludzkością, utopijną perspektywę „świetlanej przyszłości”, w której integracja poznania osiagniętego różnymi kanałami (,jedność wiedzy”) doprowadzi do całkowite- 
go wyparcia religii jako społecznego anachronizmu ${ }^{28}$. Jak nietrudno dostrzec, mamy tu do czynienia z kolejną inkarnacją oświeceniowego mitu progresywizmu, tym razem odzianego $\mathrm{w}$ atrakcyjny kostium „skorygowanego humanizmu" - tj. humanizmu poddanego wpływowi nauk ścisłych, a więc „umetafizycznionego”, wrażliwego na kulturę, „techno-sekularyzmu”. Nie zapominajmy przy tym, że ten swoisty, zrewitalizowany scjentyzm, prócz doraźnych obietnic dotyczących wiedzy i kultury, w finalnej perspektywie oferuje wydłużenie ludzkiego życia (substytut „,̇ycia wiecznego") i sklonowanie człowieka (substytut „stworzenia") - czyli manipulację w dwóch sferach nigdy przedtem ludzkości niedostępnych. Nie sposób jednak w tej krótkiej wypowiedzi zawrzeć szczegółową analizę tego zagadnienia ${ }^{29}$.

Projekt ten stawia niewatpliwie przed humanistyką nowe wyzwanie. W ten sposób bowiem na jej terenie dyskretnie odżywa nienowy, lecz posiadający wiele różnorodnych obliczy i aspektów, spór ewolucjonistów z kreacjonistami. Zauważmy, że nieuznanie biologicznej podstawy (a co za tym idzie, i ewoluującej natury) uniwersaliów ludzkiego poznania - a w dalszej konsekwencji również poiesis, twórczości - stawia sceptycznych wobec neodarwinizmu filozofów i antropologów, a za nimi również literaturoznawców, wobec pytania o alternatywne źródło owych uniwersaliów. Gdzie go szukać? Tak oto - w sposób prawdopodobnie przez bioewolucjonistów niezamierzony - implikowana ich teorią interpretacja genealogii i historycznych przekształceń ludzkiej aktywności twórczej zazębia się z, toczoną od stuleci pod różnymi hipostazami, debatą o Pierwszą Przyczynę. Debata ta zaś skłania do postawienia pytań fundamentalnych, na które nauka ze swoim racjonalizmem nie była dotąd i nadal nie jest w stanie udzielić pewnej odpowiedzi, odsuwając kwestie nimi objęte w sferę ponadracjonalnego (często błędnie określanego jako irracjonalne)

${ }_{28}$ Zob. Grant Morrison, Science, Tradition, and Utopia, „Modern Age”, vol. 43, no. 1 (Winter 2001), s. 32, 33.

29 Więcej na ten temat zob. John C. Caiazza, The Arrival of Techno-Secularism, „Modern Age", vol. 44, no. 3 (Summer 2002) i Peter Augustine Lawler, Our Friend Mr. Darwin? (Larry Arnhart, “Darwinian Conservatism”), „Modern Age”, vol. 48, no. 3 (Summer 2006), zwłaszcza s. 268. 
„objawienia” i odpowiadającej mu, indywidualnej, „subiektywnej” i niemożliwej do zweryfikowania metodami naukowymi, ,wiary”.

Projekt ewolucjonistycznych badań literackich nie uwzględnia również innych zagadnień, wyminiętych bądź zneutralizowanych (,,zdekonstruowanych") przez poststrukturalizm, a należących do aksjologii literackiej - takich, jak np. relacja między literaturą a sferą moralności i sacrum. Problematyka wartości i wartościowania w ogóle źle wpisuje się w badania, dla których alians literaturoznawstwa i sciences jest punktem wyjścia dalszych rozważań, a jego utwierdzanie, i tym samym umacnianie współpracy między humanistyką a innymi obszarami nauki (w imię „konsyliencji” czy innej teorii ,jedności wiedzy”), stanowi najważniejszy cel na horyzoncie procedur badawczych. Nawet jeśli ewolucjoniści rozpatrują estetyczne i ideowe aspekty twórczości literackiej, czynią to przede wszystkim w poszukiwaniu nadrzędnej funkcji adaptacyjnej, pomijając zarówno wartości ujawniane w literaturze, wartość samego dzieła, jak i wartości sytuacyjne twórczości $^{30}$. Spłaszczają tym samym i instrumentalizują - w imię dowiedzenia słuszności aksjomatu ewolucjonizmu - najistotniejsze wymiary literatury. Wszystko to jest ceną kompromisu, którego Carroll nie mógł wyrazić bardziej dobitnie: ,Jeżeli humanistyka nie będzie chciała dobić targu z tym konkretnym diabłem [naukami ścisłymi - D.S.] [...], skaże się na nieistotność i trywialność"31. Wprawdzie ewolucjonistyczne badania literackie mają zachować „to, co swoiste i szczególne dla natury literackiego doświadczenia" 32 , lecz jak w praktyce miałoby to wyglądać, zważywszy na sojusz literaturoznawstwa i innych dyscyplin - nie bardzo wiadomo. Przynajmniej na razie. Zasadne natomiast wydaje się pytanie, czy właśnie wchodząc w alians $\mathrm{z}$ biologicznym psychologizmem, nauka o literaturze nie ryzykuje aby popadnięcia w „nieistotność i trywialność”. Ludzkość od najdawniejszych czasów opowiada fabuły, które wpływają na świadomość i losy

\footnotetext{
30 Odwołuję się tu do klasycznego ujęcia problematyki aksjologii literackiej, przedstawionego w pracach Stefana Sawickiego (zob. S. Sawicki, Ku świadomej ocenie w badaniach literackich i Problematyka aksjologiczna w nauce o literaturze, w: Wartość - sacrum - Norwid. Studia i szkice aksjologicznoliterackie, Lublin 1994).

31 Joseph Carroll, What is Literary Darwinism? An Interview with David DiSalvo, dz. cyt.

32 Tamże.
} 
kolejnych pokoleń, lecz przecież wśród tych przekazów są zarówno moralitety i powieści, jak i dowcipy czy pornografia, twórczość popularna i wysoka, wypowiedzi artystyczne i rozmaite komunikaty medialne. Czy oznacza to, że z jednakową pieczołowitością i powaga należy zajmować się badaniem wszystkich tych odmian i trybów narracji? W imię konsekwentnego przestrzegania założeń darwinizmu literackiego wydaje się, że tak ${ }^{33}$.

Ewolucjonistyczne podejście do literatury ujawnia jeszcze jedno oblicze - redukcjonistyczne. Pole zastosowania darwinizmu literackiego w praktyce ograniczone jest założeniami tej teorii. Niewiele światła jest ona w stanie rzucić np. na te utwory, które - zamiast realizować funkcję adaptacyjną, pierwszoplanową z punktu widzenia potrzeb reprodukcji, a służącą ocaleniu gatunku na drodze selekcji naturalnej - dokonują jej transgresji, np. ukazując perspektywę trudnego humanizmu, etos działania kłócącego się z logiką biologicznego przetrwania jednostki czy nawet całej zbiorowości. A przecież dzieła te, uświadamiając istnienie imponderabiliów oraz ukazując kruchość i zarazem wielkość zmagającego się z sobą samym i ze swoim losem człowieka, stanowią niejednokrotnie najbardziej wartościowe świadectwa zdolności transcendowania ograniczeń ludzkiej natury. Próba eksplikacji tak wyrafinowanej formy kultury, jaką stanowi literatura, wyłącznie w biopsychologicznych kategoriach ,zazdrości o gen", budzić może uzasadniony sprzeciw.

Inny, lecz spokrewniony z powyższym przykład redukcjonizmu: dowodząc istnienia adaptacyjnych funkcji literatury, Carroll wskazuje na powszechność występowania ,wyobrażeniowych konstrukcji werbalnych - mitów, opowieści i odegrań dramatycznych" ${ }^{34}$, wspólnych wszystkim kulturom. Przytacza też kolejny dowód - „ontogeniczny”: „wszyscy ludzie mają powszechną, niezawodnie się rozwijającą zdol-

33 Np. Catherine Salmon (Crossing the Abyss. Erotica and the Intersection of Evolutionary Psychology and Literary Studies, w: The Literary Animal. Evolution and the Nature of Narrative, dz. cyt.) analizuje pornografię wizualną dla mężczyzn w zestawieniu $\mathrm{z}$ romansami kobiecymi.

34 Joseph Carroll, The Human Revolution and the Adaptive Function of Literature, „Philosophy and Literature", vol. 30 (2006), s. 43. 
ność wytwarzania i konsumowania narracji” ${ }^{35}$. Trudno, oczywiście, temu zaprzeczyć. Argumentacja ta jednak nie uwzględnia nie tylko różnicy jakościowej między rozmaitymi odmianami i formami owych „narracji”, o której wspomniałem wcześniej, lecz również tego, co z punktu widzenia badań humanistycznych (nie tylko literaturoznawczych, ale też np. antropologicznych) bodaj najistotniejsze - mianowicie różnicy kulturowej. Artefakty różnych kultur - i zarazem same te kultury - zostają w optyce neodarwinizmu zrównane ze sobą jako jednakowo wartościowe, a wartość ich wynika po prostu z ich uczestnictwa w procesie kształtowania i kierowania systemem wierzeń i zachowaniem jednostek i całych populacji na danym etapie rozwoju ${ }^{36}$. $\mathrm{O}$ ile trudno zapewne byłoby dopatrywać się w tym stanowisku pogłosu postmodernistycznej koncepcji ,tygla” czy odprysków multikulturalizmu, to jednak teoria Carrolla, pomimo odwołań do nader rozległych kontekstów, sięgających zarówno czasów historycznych, jak i prehistorycznych, nie wyjaśnia - i co więcej, nie zauważa - specyfiki kultury Zachodu w stosunku do innych kultur. Mówiąc językiem Rémi Brague'a, główny teoretyk darwinizmu literackiego, w wyniku przyjętych przez siebie założeń, nie jest $\mathrm{w}$ stanie dostrzec $\mathrm{w}$ tej kulturze „ekscentryczności” ${ }^{37}$ - tej unikatowej własności, będącej pochodną spotkania „Aten” z ,Jerozolimą”, która zaowocowała jedyną w swoim rodzaju w dziejach świata cywilizacją (jakkolwiek niepoprawnie politycznie może to brzmieć) - samokrytyczna, świadomą własnych braków i przez to chłonną, otwartą na „inne”.

Zdaję sobie, oczywiście, sprawę, że w dobie pluralizmu - a tym samym i ograniczenia stosowalności - teorii, niezupełnie uczciwe jest wytykanie jednej z nich tego, co stanowi jej inherentne ograniczenie, a co z powodzeniem uzupełnić może inna teoria. (Co nb. nie koliduje z tym, że teorie można wartościować, np. pod względem szczegółowości, zakresu stosowalności, zdolności wyjaśniania większej liczby bardziej złożonych i różnorodnych zjawisk etc.). Powróćmy zatem na

35 Tamże.

36 Tamże, s. 44.

37 Zob. Rémi Brague, Eccentric Culture. A Theory of Western Civilization, translated into English by Lester Samuel, South Bend 2002. Oryginał francuski Europe, la voie romaine ukazał się w 1992 r. 
główny tor rozważań. Projektodawca „darwinizmu literackiego" nie kryje nadziei, jakie wiąże z wysuniętą przez siebie propozycją. Pytany o perspektywę przebudowanych w duchu ewolucjonizmu badań literackich, udziela jednak odpowiedzi, która totalizmem zawartej w niej wizji może budzić pewne obawy:

Literaccy darwiniści muszą zasymilować najlepsze intuicje wcześniejszej teorii i krytyki, lecz muszą je przeformułować w zupełnie nowym kontekście, usytuowanym w obrębie większego obszaru obejmującego wszystkie nauki humanistyczne. [...] Muszą uczestniczyć w budowaniu powiązań między własnymi, poszczególnymi dziedzinami badań a szerszym obszarem ewolucjonistycznych nauk społecznych. Muszą stworzyć świat na now ${ }^{38}$.

Zważywszy na filozoficzno-światopoglądowy kontekst przedstawianego nurtu, ostatnie zdanie zdaje się tchnąć czymś więcej niż tylko retoryka. Ilekroć kolejna teoria zwiastuje nowy, quasi-soteriologiczny porządek rzeczy, ostrożność z pewnością nie zawadzi.

W jaki sposób - wobec wszystkiego, o czym była tu dotąd mowa uprawiać dziś naukę o literaturze? Tak, by nie zrywać związku między nią a zewnętrznym światem, a zarazem ocalić jej integralność i autonomię, co w obliczu wspomnianych tendencji do włączania literaturoznawstwa w obręb antropologii i nauk społecznych, a nawet wiązania go z naukami ścisłymi, nie jest bynajmniej rzeczą małej wagi ani hiperbolizowaniem zagrożeń? I dalej: czy wprzęganie Darwinowskiej teorii ewolucji do swoiście pojętego programu odnowy humanistyki jest dla tej ostatniej szansą, czy raczej zagrożeniem? Pomiędzy racjami radykalnego sceptycyzmu epistemologicznego a tezami obiektywizmu poznawczego, realizowanego pod przedziwnymi auspicjami techno-humanizmu, jest chyba dość przestrzeni, by „robić swoje", czyli uprawiać naukę w sposób, który z jednej strony nie będzie lekceważył teorii (pluralis), z drugiej zaś - będzie mocno ugruntowany $\mathrm{w}$ rzetelnie analizowanym, tj. niepodporządkowanym aprio-

38 Joseph Carroll, What is Literary Darwinism? An Interview with David DiSalvo, dz. cyt. 
rycznie tej czy innej, jednej teorii, materiale ${ }^{39}$, a przy tym nie będzie odrzucał przedmiotowej tożsamości literaturoznawstwa. Ewolucjonistyczna teoria literatury, ufundowana na przesłankach bioepistemologii, cechuje się, przynajmniej w swoich deklaracjach, inkluzywnością wobec poprzedzających ją ujęć i koncepcji badawczych, co można jej zapisać in plus (o ile nie rozpuści, przejętego w schedzie, inwentarza w kolejnej, tym razem po-postmodernistycznej, „zupie”). Stanowi też - po programowym odhistorycznieniu badań literackich przez postmodernizm - swoistą formułę przywrócenia perspektywy historyzmu wobec zjawisk literatury i kultury. To obiecujacca zmiana w podejściu do przedmiotu badań. Jednak roszczenia ,darwinizmu literackiego" do całkowitego przekonfigurowania humanistyki zagrażają chyba raczej jej autonomii, niż zdolne są przynieść obiecane uzdrowienie. Z kolei projekt systemowego oparcia badań literackich na ustaleniach, płynących z teorii wysuniętej w dyscyplinie tak odległej od naszej, będący $\mathrm{w}$ istocie radykalną formą ,trans-dyscyplinowej integracji”, niezbyt koresponduje z postulatem ,skorelowania profesjonalnej specjalizacji z interdyscyplinarnością (pojmowaną [...] jako stymulacja do krytycznej autorefleksji i redefinicji własnej dyscypliny)" ${ }^{30}$.

Nie przesądzajmy jednak przedwcześnie. Być może propozycja Carrolla i innych neodarwinistów zdoła przynieść ważkie rezultaty poznawcze nie tylko dla dziedziny źródłowej, a więc bioepistemologii, lecz również z punktu widzenia nauki o literaturze. W projekcie tu referowanym - przy spełnieniu pewnych warunków - może znaleźć się miejsce dla literatury traktowanej jako realny, autonomiczny przedmiot badań, a nie jedynie materiał służący do wnioskowania o zjawiskach i procesach biologicznych oraz socjopsychologicznych albo poligon do testowania zasięgu i trajektorii nowej „,broni ofensywnej” w arsenale ,zreformowanej” humanistyki. By postulat ten zrealizować, badacze sięgający po tę teorię musieliby jednak wykazać się znaczną suwerennością wobec ewentualnych doktrynerskich przyna-

\footnotetext{
39 Skłonny jestem zgodzić się z opinią Ewy Domańskiej przedstawioną w przywołanym wcześniej artykule Jakiej metodologii potrzebuje współczesna humanistyka?.

40 Ryszard Nycz, O przedmiocie studiów literackich - dziś, w: Polonistyka w przebudowie. Literaturoznawstwo - wiedza o języku - wiedza o kulturze - edukacja. Zjazd Polonistów, Kraków, 22-25 września 2004, dz. cyt., s. 16.
} 
gleń czy zapędów, mających na celu udowodnienie za wszelką cenę słuszności obranego kursu ${ }^{41}$. W przeciwnym razie należy się spodziewać, że pod piórem neodarwinistów dzieła sztuki literackiej pozostaną raczej ubocznymi produktami ewolucji niż jednymi z najcenniejszych wytworów ludzkiej aktywności. A wówczas realizacja pomysłu integracji literaturoznawstwa $\mathrm{z}$ socjobiologia, psychologią ewolucyjną i innymi dyscyplinami z pogranicza nauk ścisłych i społecznych - o ile do niej u nas dojdzie - będzie chyba jednym z bardziej bolesnych dla polonistyki doświadczeń, odbytych w „czyśćcu Teorii”, w jakim się obecnie znajdujemy. Czy zaś „literacki darwinizm” w ogóle trafi w Polsce na podatny grunt i jakie ewentualnie „wyda owoce", w tym, czy odciśnie istotniejszy ślad na przyszłej syntezie naszej literatury lub choćby na wiedzy o poszczególnych utworach czas zapewne pokaże.

\section{Summary}

\section{History of literature held in Darwin's embrace?}

The paper adumbrates Joseph Carroll's evolutionist literary theory positioning it against the developments in literary studies and humanities after postmodernism. The author discusses the ambivalence present in Carroll's neo-darwinian project, its possible power to revert the decline of literary studies through a return to tangibility and certainty after the dominance of postmodern speculative theories, but also its reductionist and anti-axiological- stance being a peril to the advancement of literary studies. The paper invites further discussion on the prospects of trans-disciplinary alliance between humanities and biological sciences in relation to the aesthetic specificity of literature.

\footnotetext{
${ }^{41}$ Por. Stefan Sawicki, O sytuacji w metodologii badań literackich, w: Wartość - sacrum - Norwid, dz. cyt. s. 42.
} 